\title{
Fuel Subsidies, the Oil Market and the World Economy
}

Nathan Balke, Michael Plante and Mine Yücel

Federal Reserve Bank of Dallas

Research Department

Working Paper 1405

Published as: Balke, Nathan S., Michael D. Plante and Mine K. Yucel (2015), "Fuel Subsidies, the Oil Market and the World Economy," The Energy Journal 36 (SI1): 99-127.

https://doi.org/10.5547/01956574.36.S11.nbal 


\title{
Fuel Subsidies, the Oil Market and the World Economy
}

\author{
Nathan Balke, Michael Plante and Mine Yucel*
}

August 2014

\begin{abstract}
This paper studies the effects of oil producing countries' fuel subsidies on the oil market and the world economy. We identify 24 oil producing countries with fuel subsidies where retail fuel prices are about 34 percent of the world price. We construct a two-country model where one country represents the oil-exporting subsidizers and the second the oil-importing bloc, and calibrate the model to match recent data. We find that the removal of subsidies would reduce the world price of oil by six percent. The removal of subsidies is unambiguously welfare enhancing for the oil-importing countries. Welfare can also improve in the oil-exporting countries, depending upon the extent to which they are net exporters of oil and on oil supply and demand elasticities.
\end{abstract}

Keywords: oil prices, fuel subsidies, fiscal policy, open economy macro JEL Classifications: E62, F41, Q43

\footnotetext{
${ }^{*}$ For helpful comments and suggestions we thank Michael Sposi, Galo Nuno, Kjetil Storesletten, Christiane Baumeister as well as participants of the USAEE 2013 and 2014 meetings, the 2014 CAMP Workshop and the 2014 Midwest Economics Association conference. Southern Methodist University, nbalke@mail.smu.edu; Federal Reserve Bank of Dallas, michael.plante@dal.frb.org; Federal Reserve Bank of Dallas, mine.k.yucel@dal.frb.org. The views presented in this paper are those of the authors alone and do not reflect the official views of the Federal Reserve Bank of Dallas or the Federal Reserve System as a whole.
} 


\section{Introduction}

Fuel subsidies are used by many developing countries to help lower the cost of energy for their people. According to the International Energy Agency (IEA) there were 37 countries with subsidies on oil products for an estimated total value of $\$ 285$ billion dollars in 2011 . In general, countries which are net exporters tend to have the largest subsidies. The size of the subsidies has skyrocketed over the last 10 years. The existence of such large and widespread subsidies undoubtedly has an effect on oil demand and world oil prices.

Despite the prevalence of fuel subsidies, there is not a large literature focusing on them. Several IMF working papers, such as Coady et al. (2006) and Kpodar (2006), have studied the distributional impacts of removing fuel subsidies on household expenditures by using social accounting matrix and input-output models. Hartley and Medlock (2008) studied the behavior of National Oil Companies (NOC's) and showed that NOC's are inefficient compared to private companies and having the NOC's subsidize domestic customers increased this inefficiency. Using a small open-economy model, Plante (2014) showed that sizable subsidies could introduce significant distortions into the country that put them in place.

What these previous studies miss is the impact that subsidies have on the world oil market in particular, and on the pattern of world trade in general. In this paper, we address this gap in the literature by developing a two-country DSGE model to analyze the effects of fuel subsidies in oil exporting countries.

In our model we assume both the oil exporters and importers produce oil, with the oil importers also manufacturing a traded, non-oil good. Oil is consumed by households in both countries and used in the production of the non-oil good. The non-oil good is used in oil production and also consumed by households in both countries.

We identify 24 oil producing countries which have fuel subsidies. We find that in recent years they consume about 13.5 percent of the world's oil, produce nearly 48 percent, and have retail fuel prices around 34 percent of world prices. To analyze the impact of these subsidies on oil markets and the global economy, we calibrate our model to match this data. We then conduct the policy experiment of permanently removing the subsidies on oil and analyze how this affects the relative price of oil, the consumption of both oil and non-oil goods, oil production, GDP and welfare in the long run.

With our benchmark calibration, the results show that removing the 
subsidies would reduce the world price of oil by about 6 percent. Consumers in oil exporting countries would re-allocate their consumption away from fuel products towards other goods while consumers and manufacturers in the oil-importing country would consume more oil. The removal of the subsidy and the consequent oil price decline act as a positive oil shock for the oil-importing country, leading to a small increase in non-oil GDP. We also analyze how the removal of subsidies affects welfare in both the oil importing and exporting countries and find that welfare in both countries increases when the subsidies are removed.

Certain factors are particularly important in determining the results. These include the elasticities of oil supply and oil demand, as well as the share of oil production and consumption in the two countries. We explored the robustness of our results to variations in these factors. The qualitative nature of our results generally holds for a variety of calibrations, and we find that removal of the subsidies is welfare enhancing for the oil importing countries in all cases considered.

On the other hand, in certain cases the removal of subsidies can cause welfare to fall in the oil-exporting countries. The reason is as follows. Fuel subsidies artificially increase the world price of oil, and as the subsidizers are large net exporters of oil they potentially stand to benefit from this distortion, at the expense of the non-subsidizers. How much they benefit depends greatly upon the price elasticity of oil import demand of the oil importers.

For our benchmark calibration, the demand facing the exporting country is elastic, and in this case removing the subsidy is welfare enhancing. However, the import elasticity of demand becomes smaller when oil supply and demand are very inelastic. In that case, the revenue consequences of removing the subsidies becomes less benign for the exporters and removing the subsidies can reduce their welfare. Essentially, the oil exporting country is unable to increase its consumption of the non-oil good enough to offset the decrease in oil consumption brought about by removing the subsidies, which produces a welfare loss.

The remainder of the paper is organized as follows. We first discuss the data used in the calibration of the model. In section 3, we introduce a stylized, analytical model to help explain the intuition behind the results of the paper. Section 4 discusses the two-country DSGE model with endogenous oil supply. In the context of this model, we examine the effects on the world economy of removing oil subsidies. We also consider a sensitivity analysis of these effects to alternative parameterizations of the model. In section 5, we end with concluding remarks. 


\section{Data}

In this section we present data on the subsidizing countries used in our calibration. We show how important these countries are to the oil market and how subsidized their prices are in relation to world prices. The data provide a clearer picture as to why subsidies are an important issue for the rest of the world. They will also be a key input into the theoretical models we will use to quantify the importance of these subsidies.

A first step is to decide which oil producing countries to label as subsidizers. We identified 24 countries that we include in the group of subsidizers, and these countries are listed in table 1 . These 24 may be a conservative estimate. We limited our attention to those countries for which there was data on retail fuel prices, and for which the data unambiguously pointed to the presence of fuel subsidies. We also left out a few countries that appear to only have had intermittent experience with fuel subsidies, such as Mexico and Brazil. ${ }^{1}$

In table 2 we show the share of world oil consumption and production for the group as a whole from 1992 up to 2012. The world oil consumption and production data come from the Energy Information Administration's International Energy Statistics database. We used their annual data on "Total Petroleum Consumption" and production of "Crude Oil, NGPL, and Other Liquids" to calculate the consumption and production shares. We start in 1992 as that is the first year that the data was available for all of the countries.

Since the early 1990s the share of world oil consumption due to these countries grew slowly, but steadily. Their share of consumption has risen from about 9 percent in 1992 to 13.5 percent in 2012. While the share is not enormous, it is not trivial either. The share of oil produced by these countries has been between 45 to 50 percent over the sample period. In 2012 the share was almost 48 percent. Taken as a whole, these countries are large net exporters of oil.

We also need to measure how distorted domestic retail prices in these countries are compared to world prices. Our data on retail fuel prices come primarily from two sources: OPEC Annual Statistical Bulletins and the World Bank's data on retail gasoline and diesel prices. The former provides annual averages for retail fuel prices in OPEC member countries, in most cases from 1990 to 2012. The World Bank data provides bi-annual estimates

\footnotetext{
${ }^{1}$ This number also reflects a lower bound on the total number of countries as it excludes some oil-importing countries with fuel subsidies. A more complete list of countries can be found in Plante (2014).
} 
of retail fuel prices in a number of other countries, typically starting in 1998 . In a few cases, media reports or other sources, such as the GIZ International Fuel Price survey, were also used. We describe the exact sources used for each country in the appendix.

We first choose a benchmark price against which to compare the subsidized prices. We use the national average retail price for gasoline and diesel in the U.S., excluding taxes, that comes from the U.S. Department of Energy. These prices may not be a perfect benchmark, but since fuel prices in the U.S. are set in a competitive market, and we have a measure of these prices that excludes taxes we believe that a large gap between retail prices in other countries and the U.S. price will almost assuredly be indicative of subsidization.

Within the context of the models we introduce later, a convenient measure of the degree of subsidization is the ratio between the subsidized price and the world price. That is, suppose $P_{s, t}$ is a domestic, subsidized price (in dollars) at time $t$ while $P_{o, t}$ is the retail price in the U.S. (excluding taxes). Then one measure of the degree of subsidization is given by

$$
\psi_{t}=\frac{P_{s, t}}{P_{o, t}}
$$

To construct $\psi_{t}$ we need to aggregate across different product prices and different countries. In doing so, we want to take into account three important factors. First, gasoline and diesel prices are often subsidized to different degrees both within and across countries. Second, consumption levels of gasoline and diesel may also vary within and across countries. Finally, some of the countries found in table 1 are larger consumers than others.

We perform the following calculations to take these factors into account. First, in a given year, for each country we calculate one ratio for gasoline prices and one for diesel prices. Then in each year, for each country, we combine the gasoline and diesel price ratios by weighting them according to the importance of gasoline consumption, vis-a-vis diesel consumption, in that particular country. Finally, in a given year we weight each country's ratio with that country's share of oil-consumption relative to the other countries as a whole, and then sum across all countries to produce $\psi_{t}$.

Using the OPEC data we can construct $\psi_{t}$ back to 1990 for 10 countries. The World Bank data allows us to construct a series from 1998 onwards for all 24 countries. Figure 1 plots the ratios for the two groups. For the small set of countries, $\psi_{t}$ indicates that they have subsidized prices over the entire sample period, and that the subsidies have increased significantly over the last 15 years. In 2012 prices in these countries were just 30 percent of 
U.S. prices. For the whole set of countries, we find a similar pattern in the behavior of $\psi_{t}$. In 2012, prices for the 24 countries were 34 percent of those found in the U.S. ${ }^{2}$

The ratio for the whole group is generally higher than the ratio for just OPEC members, reflecting the fact that certain OPEC members heavily subsidize fuel products. However, the differences are not particularly dramatic after 1998. The reason for this is that a majority of the oil that is consumed by the 24 countries is due to just a handful of countries, and they have price ratios that are very low. For example, in 2012 half of the consumption of oil out of the 24 countries was due to Indonesia, Iran, and Saudi Arabia, which had price-ratios of $.55, .32$ and .11 , respectively. The next three largest consumers were Egypt, Iraq, and Venezuela, which had price ratios of $.32, .41$, and .02 respectively. As such, the subsidization policies of these countries dominate the behavior of $\psi_{t}$.

In the next section, we use a simple model to highlight the important channels through which these subsidies could affect the oil market and the world economy. In section 4 we introduce a more sophisticated general equilibrium model which is calibrated to match the data introduced in this section. We use our calibrated model to gauge the quantitative importance of the subsidies.

\section{Motivating example}

In this section we introduce a highly stylized two-country model. The simple setup employed here produces analytical results that explicitly show how the presence of a subsidy in the oil exporting countries can affect the world price of oil and the consumption of both oil and non-oil goods. Our goal here is to highlight the important channels through which subsidies distort economic variables and highlight what factors may determine the quantitative importance of these distortions. Although the model is very simple in nature, the findings here provide good intuition for many of the results found in the more complicated model we introduce in section 4 .

\subsection{The model}

We consider a world where there are two countries, country $a$ and country $o$. The latter represents the group of net oil exporters that subsidize domestic residents' consumption of fuel products. The former represents the rest

\footnotetext{
${ }^{2}$ The exact numbers were 29.75 percent and 34.27 percent.
} 
of the world. In terms of notation, we use superscripts to refer to the two countries, so that $Z^{o}$ and $Z^{a}$ refer to variable $Z$ in country $o$ and $a$, respectively.

Both country $a$ and country o produce oil. Country o's supply of oil is given by $Y_{o}^{o}$, while country $a$ 's production of oil is given by $Y_{o}^{a}$. Country $a$ also produces a non-oil good that one can view as manufactures and other goods that are primarily produced outside of oil exporting countries. The two goods are consumed by households in both countries. The countries trade with each other, and country $a$ is a net importer of oil. We assume the non-oil good is the numeraire and denote the relative price of oil on the world market as $P_{o}$.

Total demand for oil in $o$ and $a$ is given by $O^{o}$ and $O^{a}$, respectively. Demand for oil on the part of country $a$ can be broken down further into demand due to household consumption, $O_{c}^{a}$, and demand for oil for use in production of the non-oil good, $O_{y}^{a}$, so that $O^{a}=O_{c}^{a}+O_{y}^{a}$. However, for this section we only model the behavior of overall demand $O^{a}$. Consumers in $a$ pay the world price for oil, $P_{o}$, while consumers in $o$ pay a potentially subsidized price given by $P_{s}$. We define $\epsilon \geq 0$ as the absolute value of the price-elasticity of demand for fuel products and assume it is the same for country $o$ and country $a$. We assume that the supply of oil is responsive to changes in the world price of oil. The elasticity of supply of oil for country $o$ and country $a$ is denoted as $\eta^{o}$ and $\eta^{a}$, respectively.

Let $\chi^{o}$ denote the share of world oil production due to country $o$,

$$
\chi^{o}=\frac{Y_{o}^{o}}{Y_{o}^{a}+Y_{o}^{o}} .
$$

The share of world oil consumption due to country $o$ is given by $\theta^{\circ}$,

$$
\theta^{o}=\frac{O^{o}}{O^{a}+O^{o}}
$$

Note that since country $a$ imports oil from country $o, \chi^{o}>\theta^{o}$.

The market clearing condition for the oil market is given by

$$
O^{a}+O^{o}=Y_{o}^{a}+Y_{o}^{o} .
$$

The world oil price, $P_{o}$, adjusts to ensure this condition holds.

The revenue country $o$ receives from exporting oil to country $a$ is given by $P_{o}\left(Y_{o}^{o}-O^{o}\right)$. This can also be re-written as $P_{o}\left(O^{a}-Y_{o}^{a}\right)$, which is the oil import bill for country $a$. 
For the non-oil good, we assume country $a$ is endowed with a fixed supply given by $Y_{a}^{a}$. The non-oil good is either consumed or used as an input to produce oil (rigs, services, so on). Let $A_{c}^{a}$ and $A_{c}^{o}$ be amounts consumed by country $a$ and country $o$, respectively, while $A_{y}^{a}$ and $A_{y}^{o}$ are the quantities of the non-oil good used in the production of oil. The use of the non-oil good in the production of oil implies that for both countries there is an opportunity cost of producing more oil. ${ }^{3}$ The market clearing condition for non-oil good is given by

$$
Y_{a}^{a}=A_{c}^{a}+A_{y}^{a}+A_{c}^{o}+A_{y}^{o}
$$

\subsection{Effects of the subsidy on the oil market}

Consider a policy in country $o$ which changes the domestic price of fuel products, $P_{s}$. We consider an unspecified percent change in the price, $\% \Delta P_{s}$. In the context of the simple model above, the change in oil consumption in country $o$ would be given by

$$
\% \Delta O^{o}=-\epsilon \% \Delta P_{s} .
$$

Not surprisingly, a reduction in $P_{s}$ would lead to an increase in consumption of oil products in country $o$, with the size of the response being determined by the price-elasticity of demand.

In turn, the increase in demand for oil by country $o$ will result in a change in the world market price of oil, $P_{o}$. From equation (2), the change in the world price of oil must satisfy:

$$
-\left(1-\theta^{o}\right) \epsilon \% \Delta P_{o}-\theta^{o} \epsilon \% \Delta P_{s}=\left[\left(1-\chi^{o}\right) \eta^{a}+\chi^{o} \eta^{o}\right] \% \Delta P_{o} .
$$

Solving (5) for $\% \Delta P_{o}$ yields:

$$
\% \Delta P_{o}=\frac{-\theta_{o} \epsilon}{\left(1-\theta^{o}\right) \epsilon+\left(1-\chi^{o}\right) \eta^{a}+\chi^{o} \eta^{o}} \% \Delta P_{s} .
$$

Thus, a change in the subsidized price moves the world oil price in the opposite direction, as the world price adjusts to clear the oil market. As a result of higher world oil prices, consumption of oil in country $a$ is crowded out by the subsidy,

$$
\% \Delta O^{a}=\epsilon \frac{\theta_{o} \epsilon}{\left(1-\theta^{o}\right) \epsilon+\left(1-\chi^{o}\right) \eta^{a}+\chi^{o} \eta^{o}} \% \Delta P_{s} .
$$

\footnotetext{
${ }^{3}$ One can obviously consider other resources that might be used in the production of oil, such as labor, non-traded services, etc. All of these would introduce the notion that there is an opportunity cost associated with changing the supply of oil, and would introduce various distortions in the model.
} 
The size of the changes in $P_{o}$ and $O^{a}$ depend upon the elasticities of demand and supply as well as the shares of the two countries in the consumption and production of oil. In general, the larger the share of country $o$ in world oil usage $\left(\theta^{\circ}\right)$, the bigger the effect a change in the subsidized price has on the world oil price. Intuitively, if the subsidizing countries are large, then even a small change in $P_{s}$ will have a large effect on the world price of oil. On the other hand, the larger the elasticity of world oil supply $\left(\left(1-\chi^{o}\right) \eta^{a}+\chi^{o} \eta^{o}\right)$, the smaller effect a change in the subsidized price has on the world oil price. With supply more responsive, less crowding out of country $a$ 's oil consumption needs to occur to clear the market, and, as a result, prices need to change by less in response to the increase in oil demand by the subsidizing country.

Finally, total world consumption of oil may also be affected when $P_{s}$ changes. Note, though, that the supply elasticities play a key role in this result. If supply elasticities are zero then increases or decreases in $P_{s}$ merely re-allocate consumption across countries but have no impact on overall consumption. When $\eta^{a}, \eta^{o}$ or both are non-zero reductions in $P_{s}$ would increase world oil consumption.

\subsection{Effects of the subsidy on export revenues and trade}

Since the subsidy affects the world price of oil, $P_{o}$, it has implications for the terms of trade between the two countries. More specifically, as an exporter of oil, country o's terms of trade are positively (negatively) affected by the presence (removal) of a subsidy. This may have implications for country $o$ 's oil export revenues and its ability to purchase non-oil goods from $a$.

The amount of the non-oil good that country $o$ can purchase depends on the revenue it receives from exporting oil to $a$. The current account equation for country $o$ links up these two quantities and is given by:

$$
P_{o}\left(O^{a}-Y_{o}^{a}\right)=A_{c}^{o}+A_{y}^{o} .
$$

A change in the subsidized price $P_{s}$ will change country o's export revenue for two reasons. First, it will affect the price $o$ receives for the oil it exports. Second, the subsidy will also affect the quantity of oil that country $a$ imports. The total impact of these two effects on the oil import bill of $a$ will depend upon how responsive country $a$ 's production and consumption of oil is to the change in $P_{o}$.

A convenient way to think about the total impact is to consider the price elasticity of oil import demand in country $a$, which we define as $\xi^{a}$. The 
response of export revenue to changes in the world price of oil is then given by

$$
\% \Delta\left[P_{o}\left(O^{a}-Y_{o}^{a}\right)\right]=\left(1-\xi^{a}\right) \% \Delta P_{o} .
$$

By definition, whether oil export revenue for country o rises or falls when the market oil price rises depends on whether $\xi^{a}$ is less than or greater than 1 . If import demand is inelastic $\left(\xi^{a}<1\right)$ then a rise in $P_{o}$ will increase country $o$ 's oil export revenue, as the increase in $P_{o}$ more than compensates for the decline in the quantity of oil imported by country $a$. If import demand is elastic $\left(\xi^{a}>1\right)$ the opposite occurs and country o's export revenue falls when $P_{o}$ increases.

The solution for $\xi^{a}$ can be derived using the left-hand side of equation (8). Formally, the import demand elasticity is given by

$$
\xi^{a}=\frac{\left(1-\theta^{o}\right) \epsilon+\left(1-\chi^{o}\right) \eta^{a}}{\chi^{o}-\theta^{o}} .
$$

Note that the import demand elasticity depends not just on country a's oil demand elasticity, but also on country a's elasticity of supply and the shares of country $a$ in world oil use and production. Only in the special case where country $a$ imports all of its oil $\left(\chi^{o}=1\right)$ is $\xi^{a}=\epsilon$.

Small elasticities of demand $(\epsilon)$ and supply $\left(\eta^{a}\right)$ make it more likely that import demand is inelastic. Similarly, the more country a relies on imports of oil (the higher $\chi^{o}$ is relative to $\theta^{o}$ ), the more likely import demand will be inelastic. While empirical evidence suggests that the elasticity of demand for oil $(\epsilon)$ is less than one, this does not necessarily guarantee that country $o$ 's oil export revenues will rise when $P_{o}$ rises.

What happens to oil export revenue is important because it helps determine how much of the non-oil good country o can purchase. If the imposition of the subsidy (which increases the world price of oil) raises oil export revenue $\left(\xi^{a}<1\right)$, income is transferred from $a$ to $o$ which allows country $o$ to purchase more of the non-oil good. On the other hand, if oil export revenues fall when the price of oil increases $\left(\xi^{a}>1\right)$, country $o$ would be able to purchase less of the non-oil good.

\subsection{Effects of the subsidy on welfare}

The previous results have interesting implications for the welfare effects of the subsidy on country $o$. More specifically, when $\xi^{a}<1$ the subsidy, by raising the world price of oil, inflates country o's oil export revenue. This

creates a benefit for country $o$ at the expense of country $a$ and allows $o$ 
to increase its purchases of the non-oil good. In this case, the subsidy may be welfare enhancing for country $o$ if it allows them to increase their consumption of non-oil goods.

We note, however, that an increase in export revenue is not sufficient to ensure that country $o$ will actually be better off. To the extent that country $o$ produces more oil, this increases the costs associated with producing oil, given by $A_{y}^{o}$. The increase in costs offset the benefit that accrues to $o$ from the inflated world price of oil because they spend part of the extra income on importing goods used to produce oil instead of on consumption goods.

When $\xi^{a} \geq 1$, it seems more likely that the subsidy will reduce welfare in country $o$. In that case, the increase in domestic consumption of oil that the subsidy brings about would have to be met with a decline in the consumption of the non-oil good.

The effect of the subsidy on country $a$ appears likely to be negative, especially if $\xi^{a} \leq 1$. The subsidy, by raising the world oil price, crowds out the consumption of oil in $a$. Furthermore, to the extent that country $a$ ends up increasing its domestic oil production, the quantity of the non-oil good used in production of oil $\left(A_{y}^{a}\right)$ will rise, leaving fewer resources available for consumption. When $\xi^{a}<1$, the subsidy also inflates country $a$ 's oil import bill, transferring income from $a$ to $o$. If $\xi^{a}>1$, this effect works to the benefit of $a$, but we suspect that this will be relatively more important for $o$ than $a$.

\subsection{Summary}

The results in this section highlight several channels through which fuel subsidies can distort both the oil market and the world economy. The solutions suggest that the quantitative importance of the subsidies will depend upon factors such as how much oil the subsidizing countries consume, how much oil the non-subsidizing countries produce, the values of elasticities of demand and supply in the two countries, and how large the subsidies are.

We have also found that the various channels may have different implications for the two countries. For country $o$, at least one of the channels may operate as a benefit from their perspective, at the expense of country $a$. The strength of this channel depends upon the price elasticity of oil import demand in country $a$, the value of which is determined by how much oil country $a$ produces and consumes relative to country $o$, as well as on country $a$ 's elasticities of oil supply and demand. If import demand is inelastic enough, the subsidy could actually be welfare enhancing for country $o$.

To help with the exposition of the simple model, we wrote the model as if 
the country shares in production and consumption of oil and the elasticities of supply and demand were primitives. However, it is clear that quantitative values of these parameters are in fact related to one another. In the next section we introduce a more sophisticated general equilibrium model where these key share and elasticity parameters are related to underlying parameters describing tastes and technology. We calibrate the general equilibrium model to match various features of the data, including those outlined in section 2. We then use this model to quantify the impacts of the subsidies on both countries.

\section{Model and results}

We now introduce a two-country dynamic general equilibrium model. In this model we make the production of both oil and non-oil goods endogenous. As before, the countries are denoted as $a$ and $o$, and superscripts are used to distinguish the countries. A representative firm in country a produces the non-oil good using labor, capital, and oil as inputs. Oil is produced in both countries using the non-oil good as an input. As before, country $a$ is a net importer of oil.

In our policy experiments, we work primarily with the steady state version of the model. However, we introduce the fully dynamic version here to describe where the steady state equations come from. At certain points in the discussion we simplify the presentation of the equations for brevity's

sake. All of the equations from the model, along with their steady state versions, can be found in the appendix.

\subsection{Country a}

\subsubsection{The Household}

A representative household in country $a$ derives utility from the consumption of oil and non-oil goods, given by $O_{c, t}^{a}$ and $A_{c, t}^{a}$, respectively. The household also derives dis-utility from providing labor, denoted as $N_{t}^{a}$, to the firms that produce good $A$. We assume that aggregate consumption, given by $C_{t}^{a}$, is a CES aggregation of the two consumption goods,

$$
C_{t}^{a}=\left[\left(1-\gamma_{o}^{a}\right) A_{c, t}^{a 1-\mu_{c}}+\left(\gamma_{o}^{a}\right) O_{c, t}^{a 1-\mu_{c}}\right]^{\frac{1}{1-\mu_{c}}}
$$

where $\gamma_{o}^{a}$ is the consumption-expenditure share of oil in country $a$ and $\mu_{c}$ is the inverse of the price-elasticity of demand for fuel. 
The household maximizes lifetime utility

$$
E_{0} \sum_{t=0}^{\infty} \beta^{t}\left(\frac{C_{t}^{a 1-\sigma}}{1-\sigma}-\kappa \frac{N_{t}^{a} 1+\mu_{n}}{1+\mu_{n}}\right),
$$

where $\beta$ is the discount factor, the parameter $\sigma$ is the relative risk aversion parameter, $\kappa$ reflects the weight that households place on leisure relative to consumption, and $\mu_{n}$ is the inverse of the Frisch elasticity of labor supply.

Utility is maximized subject to the budget constraint

$$
A_{c, t}^{a}+P_{o, t} O_{c, t}^{a}+A_{I, t}^{a}=W_{t}^{a} N_{t}^{a}+r_{t}^{a} K_{t-1}^{a}+\Pi_{a, t}^{a}+\Pi_{o, t}^{a},
$$

where $P_{o, t}$ is the relative price of oil, $A_{I, t}^{a}$ is gross investment in the capital good, $W_{t}^{a}$ is the wage, and $r_{t}^{a}$ is the return to capital. Households own the firms that operate in the economy and, as a result, receive any profits from both the oil sector, $\Pi_{o, t}^{a}$, and the non-oil sector, $\Pi_{a, t}^{a}$.

Capital accumulation follows the standard law of motion

$$
K_{t}^{a}-K_{t-1}^{a}=A_{I, t}^{a}-\delta K_{t-1}^{a} .
$$

Our notation implies that $K_{t-1}^{a}$ is a pre-determined state variable in the model. When deriving first order conditions for the household's problem we substitute out $A_{I, t}^{a}$ using the law of motion for capital.

First-order conditions for the household's problem are given by

$$
\begin{aligned}
M U_{a, t}^{a} & =\lambda_{t}^{a}, \\
M U_{o, t}^{a} & =P_{o, t} \lambda_{t}^{a}, \\
M U_{n, t}^{a} & =W_{t}^{a} \lambda_{t}^{a}, \\
\lambda_{t}^{a} & =\beta E_{t} \lambda_{t+1}^{a}\left[r_{t+1}^{a}+(1-\delta)\right],
\end{aligned}
$$

where $M U_{a, t}^{a}, M U_{o, t}^{a}$, and $M U_{n, t}^{a}$ are the marginal utilities for the consumption of the non-oil good, the oil good, and labor, respectively, and $\lambda_{t}^{a}$ is the multiplier on the budget constraint.

\subsubsection{Production of the non-oil good}

Production of the non-oil good is done by a representative firm in country $a$ using capital, labor, and oil. In the production function, capital and oil are combined to produce a capital service which is then combined with labor to produce good $A$. The exact production function is

$$
Y_{a, t}^{a}=Z_{y, t}^{a} N_{t}^{a \alpha}\left[\omega_{y}^{a} K_{t-1}^{a 1-\nu}+\left(1-\omega_{y}^{a}\right) O_{y, t}^{a 1-\nu}\right]^{\frac{1-\alpha}{1-\nu}},
$$


where $Y_{a, t}^{a}$ is production of the non-oil good in country $a, Z_{y, t}^{a}$ is total factor productivity, and $O_{y, t}^{a}$ is oil used by the firm in country $a$. The parameter $\alpha$ is the share of labor in gross-output and $\nu$ is the elasticity of substitution between oil and the capital in the production of capital service. ${ }^{4}$

The representative producer of the non-oil good maximizes profit

$$
\Pi_{t}^{a}=Y_{a, t}^{a}-r_{t}^{a} K_{t-1}^{a}-W_{t}^{a} N_{t}^{a}-P_{o, t} O_{y, t}^{a} .
$$

The first order conditions are:

$$
\begin{aligned}
M P_{n, t}^{a} & =W_{t}^{a}, \\
M P_{k, t}^{a} & =r_{t}^{a}, \\
M P_{o, t}^{a} & =P_{o, t} .
\end{aligned}
$$

Here $M P_{i, t}^{a}$ is the marginal product of output with respect to capital, labor, and oil for $i=k, n, o$, respectively.

\subsubsection{Production of oil}

A profit maximizing firm produces oil in country $a$. Oil production costs are given by $A_{y, t}^{a}$ and are an increasing function of oil output. The oil producing firm in country $a$ chooses its production level to maximize:

$$
\Pi_{o, t}^{a}=P_{o, t} Y_{o, t}^{a}-A_{y, t}^{a},
$$

where

$$
A_{y, t}^{a}=\varkappa_{a} \frac{\left(Y_{o, t}^{a}\right)^{1+\frac{1}{\eta^{a}}}}{1+\frac{1}{\eta^{a}}} .
$$

The production costs are in terms of the non-oil good $A$. One can think of this as the drilling rigs, oil equipment, or any non-oil good that is used to produce oil. Although we don't model depletion, costs increase with increased oil production, reflecting the difficulty of finding additional oil as more oil is produced. The optimal quantity of oil production satisfies:

$$
P_{o, t}=\varkappa_{a}\left(Y_{o, t}^{a}\right)^{\frac{1}{\eta^{a}}}
$$

Using equation (A.4), one observes that country $a$ 's elasticity of oil supply is given by $\eta^{a} .^{5}$

\footnotetext{
${ }^{4}$ Like much of the macroeconomics literature, we assume the elasticity of substitution between labor and the capital service is one.

${ }^{5}$ The cost function also implies that the higher the elasticity of supply, the lower the marginal cost of producing a given amount of oil.
} 


\subsection{Country o}

\subsubsection{The Household}

Like that in country $a$, the representative household in country $o$ derives utility from the consumption of the non-oil and oil goods, given by $A_{c, t}^{o}$ and $O_{c, t}^{o}$, respectively. As in country $a$, these two goods are aggregated using a CES production function to generate aggregate consumption, $C_{t}^{o}$. The household maximizes

$$
E_{0} \sum_{t=0}^{\infty} \beta^{t} \frac{\left(C_{t}^{o}\right)^{1-\sigma}}{1-\sigma}
$$

with

$$
C_{t}^{o}=\left[\left(1-\gamma_{o}^{o}\right) A_{c, t}^{o 1-\mu_{c}}+\left(\gamma_{o}^{o}\right) O_{c, t}^{o 1-\mu_{c}}\right]^{\frac{1}{1-\mu_{c}}}
$$

and subject to the budget constraint

$$
A_{c, t}^{o}+P_{s, t} O_{c, t}^{o}=T_{t} .
$$

Here $P_{s, t}$ is the potentially subsidized price of oil products in country $o$ and $T_{t}$ are lump-sum transfers from the government to the representative household.

The first-order conditions for the household are

$$
\begin{aligned}
& M U_{a, t}^{o}=\lambda_{t}^{o}, \\
& M U_{o, t}^{o}=P_{s, t} \lambda_{t}^{o},
\end{aligned}
$$

where $M U_{a, t}^{o}$ and $M U_{o, t}^{o}$ are the marginal utilities for the consumption of the manufactured good and the oil good, respectively, and $\lambda_{t}^{o}$ is the multiplier on the budget constraint.

\subsubsection{Production of oil}

In many of the countries found in Table 1 the government is heavily involved in the production of oil, often through a national oil company. In line with this we assume the government, through a national oil company, controls the production of oil in country $o$. The company sells a portion of its production domestically at the subsidized prices $P_{t}^{s}$, exports the remainder at the world price $P_{t}^{o}$, and then transfers its revenue to the government.

The oil producer hence chooses production, $Y_{o, t}^{o}$, to maximize:

$$
\Pi_{t}^{o}=P_{o, t}\left(Y_{o, t}^{o}-O_{c, t}^{o}\right)+P_{s, t} O_{c, t}^{o}-A_{y, t}^{o},
$$


where the cost function is similar to country a's:

$$
A_{y, t}^{o}=\varkappa_{o} \frac{\left(Y_{o, t}^{o}\right)^{1+\frac{1}{\eta^{o}}}}{1+\frac{1}{\eta^{o}}} .
$$

The optimal quantity of production satisfies:

$$
P_{o, t}=\varkappa_{o}\left(Y_{o, t}^{o}\right)^{\frac{1}{\eta^{o}}}
$$

where the elasticity of supply is given by $\eta^{o}$.

Oil revenues are infused into the economy in a lump-sum manner, with the value given by $T_{t}$. Each period the government must satisfy its budget constraint,

$$
P_{t}^{o}\left(Y_{o}^{o}-O_{c, t}^{o}\right)+P_{t}^{s} O_{c, t}^{o}-A_{y, t}^{o}=T_{t} .
$$

The transfer $T_{t}$ in the household budget constraint is equal to net revenue from oil production, taking into account the subsidy and the costs of production. Note that if the government decides to sell oil at a reduced price to domestic households this lowers its overall revenue from the sale of oil, holding all else constant. This means that there is no free lunch from the subsidy as higher subsides mean lower distributions of income flow to the representative household.

Note also that at the aggregate, the subsidy does not, by itself, directly affect national income in country $o$. This can be seen by combining the government budget constraint, equation (35), with the household budget constraint, equation (29). This produces the current account equation for country $O$

$$
P_{t}^{o}\left(Y_{o, t}^{o}-O_{c, t}^{o}\right)=A_{c, t}^{o}+A_{y, t}^{o} .
$$

The subsidy only affects the income available to country $o$ indirectly by changing the amount of oil consumed by domestic residents, which alters the quantity of oil available for export, by changing the world price of oil, and by changing oil production levels, which affects the level of costs.

\subsection{Market clearing and the current account}

Market clearing conditions for both goods imply that total demand must equal total supply. The market clearing condition in the oil market is

$$
O_{c, t}^{a}+O_{y, t}^{a}+O_{c, t}^{o}=Y_{o, t}^{o}+Y_{o, t}^{a} .
$$

For the non-oil good the condition is

$$
A_{c, t}^{a}+A_{I, t}^{a}+A_{c, t}^{o}+A_{y, t}^{a}+A_{y, t}^{o}=Y_{a, t}^{a} .
$$


Combining the market clearing conditions and the current account equation for country $o$ given by equation (36) yields a current account equation for country $a$ given by

$$
P_{o, t}\left(O_{c, t}^{a}+O_{y, t}^{a}-Y_{o, t}^{a}\right)=Y_{a, t}^{a}-A_{c, t}^{a}-A_{I, t}^{a}-A_{y, t}^{a}
$$

This equation simply states that the dollar value of the oil imported into country $a$ at time $t$ must equal the dollar value of the goods it exports to country $o$. The connection between imports and exports can be made explicit by re-writing this equation as

$$
P_{o, t}\left(O_{c, t}^{a}+O_{y, t}^{a}-Y_{o, t}^{a}\right)=A_{c, t}^{o}+A_{y, t}^{o} .
$$

\subsection{Calibration}

The model is calibrated to an initial steady state that is consistent with recent economic data. The frequency is annual. Units are chosen so that GDP in the oil-importing countries equals 1 . The steady state values of the model's variables are chosen so as to match a set of statistics outlined in table 3 .

We calibrate the consumption-expenditure share of oil in the oil-importing countries at 5 percent. This is based on recent CPI-weights for the U.S., the EU-27, and Japan. Firm use of oil products in $a$ is set at 2 percent of GDP, based on recent data from input-output tables for many OECD countries. Investment spending in $a$ is set at 20 percent of GDP. Consistent with the data in table 2 we set the consumption of oil in the oil-exporting countries at 13.5 percent of world consumption. Their share of world oil production is set at 48 percent. The value of $P_{s}$ is set so that the subsidized price is 34 percent of the world price.

Table 3 also lists the calibration for the model's parameters. We choose the discount factor to be consistent with annual real interest rates in the U.S. Many of the other parameters are calibrated using settings frequently found in the macro literature.

The oil-related elasticities merit further discussion. The elasticities of substitution are calibrated to match longer-run price elasticities of demand for fuel products. We use previous estimates in the literature to guide our calibration. Hausman and Newey (1995) found a long-run price elasticity near -0.80 for gasoline demand in the U.S. Yatchew and No (2001) found a similar elasticity for Canada. Kilian and Murphy (2014) found a shortrun elasticity of global demand for oil of -0.26 . Baumeister and Peersman (2012) found estimates slightly below that. Graham and Glaister (2002) 
surveyed estimates of short and long-run elasticities of demand for fuel. Short-run estimates were clustered between -0.35 and -0.25 , while longerrun elasticities were larger and typically closer to -0.80. Given our model's annual frequency and the focus on longer-run implications of subsidies, we choose a baseline calibration for the elasticities of substitution of -0.75 . We consider several other possibilities for sensitivity analysis.

Supply elasticity estimates are sparse in the literature, but tend to be small. Baumeister and Peersman (2012) find that recent estimates of shortrun global supply elasticity are less than 0.2. The results in Kilian and Murphy (2012) also suggest small supply elasticities. We set our supply elasticities to 0.3 but also consider several other possibilities for sensitivity analysis. The elasticities are set equal across countries, consistent with the data that two blocs have produced a relatively stable share of world oil production.

\subsection{Policy experiment}

Our policy experiment is as follows. We first assume the world is in an initial steady state consistent with our calibration and the model's equations. We then ask what would happen if the subsidies in country $o$ were permanently removed. In the context of the model, this is done by equalizing fuel prices across countries.

We focus on the long-run impact of this policy change, i.e. we ask how the steady state of the model is affected. Technically, we conduct a comparative statics exercise. For each variable of interest we numerically calculate the percent change of that variable across steady states.

\subsection{Results}

Our results are presented in table 4 . The first column lists the variables considered with prices first, followed by variables for country $o$, variables for country $a$, and finally world oil consumption. The second column shows the percent changes across steady states for the different variables.

Under the baseline, we find that the removal of the subsidy has a nontrivial impact on the world price of oil: the model predicts that prices would decline by over 6 percent. Lower oil prices bring about a decline in oil production of equal magnitude in both countries, as the supply elasticities are equal. Domestic prices in $o$ need to rise by over 175 percent to get them equal to the new world price of oil.

The equalization of fuel prices across the two blocs of countries leads to a 
re-allocation of oil consumption. Oil consumption declines in the subsidizing countries by over 45 percent, while consumption by households and firms in country $a$ rises by about 5 percent.

In country $o$, the removal of the subsidy eliminates the price distortions which had led to over-consumption of oil and and over-investment in the oil industry. Consumers increase their consumption of good $a$, with nonoil consumption rising by about 15 percent. This increase occurs for two reasons. First, the relative price of fuel in country $o$ is now significantly higher. Second, the fall in oil production lowers production costs and releases some of good A that was used in the oil sector, for consumption.

In terms of GDP (non-oil) in country $a$, the decline in the world price of oil leads to a small positive increase in country $a$ 's non-oil GDP. Intuitively, the elevated prices that were due to the subsidies being in place before the policy change acted like an oil supply shock which reduced (non-oil) GDP in country $a$. With the subsidies removed, world oil prices decline and act like a positive oil supply shock for country $a$.

\subsubsection{Welfare Implications}

In addition to asking how variables changed across steady states, we also calculated how steady state welfare in country $a$ and $o$ was affected by the policy change. To do this, we solve for how much aggregate consumption would need to be decreased in the new steady state (with no subsidies) in order for welfare to be the same as in the old steady state (with subsidies). We convert these numbers into percentages which show the welfare gain (or loss) from removing the subsidies. If this number is positive, it means that the country experienced a welfare gain. The opposite holds if the number is negative. The exact details of the calculations can be found in the appendix.

The welfare results are presented in Table 4 . We find that removing the subsidies is welfare enhancing for both blocs of countries. For country $a$, the welfare gain is about 0.2 percent of steady state aggregate consumption. The welfare gains are higher for country $o$, which sees a gain of close to 0.9 percent.

Based on the intuition derived in Section 3, the results for country $a$ are not entirely surprising. The subsidy drives up the world price of oil and essentially acts as a negative oil supply shock that reduces consumption of oil by both households and firms in $a$. It also introduces other distortions as it leads to over-production of oil in country $a$. When the subsidy is removed, these distortions are eliminated, which improves welfare in $a$.

As discussed in Section 3, there was a possibility that removal of the 
subsidy could either increase or decrease welfare in country $o$. This is due to the fact that the subsidy artificially inflates the world price of oil, which could raise country o's oil export revenue. But whether this actually occurs depends on the price elasticity of oil import demand in country $a$, which we had denoted as $\xi^{a}$. For our baseline calibration, equation (10) suggests an estimate for $\xi^{a}$ at around 2.3, implying that removing the subsidies actually increases country $o$ 's export revenues. As a result, country $o$ 's welfare improves when the subsidy is removed.

\subsubsection{Varying supply and demand elasticities}

The solutions in Section 3 suggest that both supply and demand elasticities can play an important role in the results. Given that there is some uncertainty about these elasticities, we also considered a range of alternative values for these parameters. For each alternative calibration we consider, we repeat our policy experiment as described before.

\section{Alternative supply elasticities}

We considered four alternative values for the supply elasticities: 0.1, 0.2, 0.3 , and 0.4. The results for each parameter setting are found in table 5 . We find that the less elastic the supply, the larger the decline in world oil prices. Oil prices decline almost 8 percent when $\eta^{a}$ and $\eta^{o}$ are set to 0.1 . A larger fall in oil prices implies there is less of a price differential to be made up by the new domestic price $\left(P_{S}\right)$ in country $o$. Hence, there is a smaller percentage increase in fuel prices in $o$ for lower supply elasticities.

The benefits of removing the subsidy are larger for country $a$ as supply becomes more inelastic. Oil prices fall more, and consumption of both oil and non-oil goods rises by a larger amount, as does non-oil GDP. Not surprisingly, the welfare gains that accrue to country $a$ from the removal of the subsidy grow as supply becomes more inelastic.

For country $o$ we find that the benefits of removing the subsidy decrease as supply becomes more inelastic. Oil consumption falls by more and nonoil consumption rises by less. We also find that removing the subsidy can actually lead to a welfare decline in country $o$ when supply is very inelastic $\left(\eta^{j}=0.1\right)$. One reason is that the mis-allocation of resources devoted to producing oil is less (supply responds less to distorted oil prices), which reduces a potential benefit of removing the subsidy. Another reason is that the elasticity of oil import demand in country $a$ becomes smaller as country a's oil supply becomes less elastic. As a result, removing the subsidy has less benign implications for country o's oil export revenue.

\section{Alternative demand elasticities}


The demand elasticities are determined by the settings for the elasticities of substitution. We considered alternative calibrations for the elasticities of substitution of $0.45,0.55,0.65$ and 0.75 . We view these as plausible ranges given the time-frame we are considering with our policy experiment and the estimates of price elasticities found in the literature. Table 6 contains the results for the alternative elasticities of substitution.

We find that varying the price elasticities has a minor impact on the world price of oil. The price decline ranges from 6.1 percent to 5.7 percent. The fact that less elastic demand generates smaller price responses is somewhat counter-intuitive and deserves further discussion. A lower elasticity of demand has two implications for the consumption of oil. On the one hand, it reduces the responsiveness of consumer demand in country $o$ to changes in their domestic price. As a result, removing the subsidy brings about a smaller decline in their consumption, which means that oil exports from country $o$ also increase by less. This creates less pressure on world oil prices. On the other hand, the lower elasticity also implies that consumers in $a$ need to see bigger changes in prices to get them to consume oil. Overall, country $o$ drives the results.

For country $o$, there are important quantitative and qualitative differences in the results. As demand becomes more inelastic, oil consumption falls by less and non-oil consumption rises by less. We also find that welfare in $o$ is significantly affected by demand elasticities. If demand is inelastic enough, it is possible to experience a welfare loss from removing the subsidy. This is reminiscent of the results for low supply elasticities. As the price elasticity of oil demand falls, so too does the price elasticity of oil import demand for country $a$.

For country $a$ we find that the implications of less elastic demand are not as dramatic as what occurs in country $o$. Oil consumption rises by less, but non-oil GDP and welfare are not significantly affected. We do note, however, the non-oil consumption rises by more as demand becomes less elastic. This result is due in part to the lower oil import elasticities, which lead to greater consumption of non-oil goods (coming at the expense of country $o$ ).

\subsubsection{Other factors that affect welfare}

Analytical results in Section 3 also suggested that the share of world oil consumption due to $o$, denoted by $\theta^{\circ}$, and the share of world oil production due to $o$, denoted as $\chi^{o}$ could be important. The values of $\theta^{o}$ and $\chi^{o}$ jointly determine the degree to which country $o$ is a net exporter and also influence the import elasticity of demand in country $a, \xi^{a}$. The value of $\theta^{o}$ also plays 
a key role in determining how big of an impact subsidies have on the world price of oil.

It interesting to ask how varying these two parameters would influence the results. To do so we consider several different cases where we vary the values of $\chi^{o}$ and $\theta^{\circ}$. To motivate some different calibrations we turn to the data. We first consider a calibration for $\theta^{\circ}$ of 0.03 and $\chi^{o}$ of 0.13 . These are motivated by the data for the largest single producer and consumer among the 24 countries: Saudi Arabia. Our second calibration sets $\theta^{\circ}$ to 0.082 and $\chi^{o}$ to .23 , consistent with the data for the top five consumers amongst the group of 24: Egypt, Indonesia, Iran, Saudi Arabia, and Venezuela. In each case, we re-calibrate the model and repeat our policy experiment of removing the subsidies. Our results are contained in table 7 .

We find that the change in the world price of oil is larger as more countries are included in the exporting group. This is not surprising, given that their share of world oil consumption rises. We also find that country $a$ is more positively affected by the removal of the subsidy as the subsidizing group becomes a larger producer and consumer of oil. When country $o$ only consumes 3 percent of the world's oil, the price impact of removing subsidies are relatively small, and therefore the impact this policy change has on country $a$ is small. These impacts become larger as more countries are added in.

From country o's perspective, we find that the results are qualitatively similar to the baseline case in that oil consumption falls, non-oil consumption rises, and country $o$ sees welfare gains from removing the subsidy in all three cases. We note that the gains are significantly larger in the two alternative calibrations. This is in line with the intuition from Section 3; in both alternative calibrations, the import elasticity of demand in country $a$ is significantly higher than the baseline calibration. This makes it much more likely that removing the subsidy increases welfare in country $o$.

We note, though, that the above welfare results are mixing together the implications of varying $\chi^{o}$ and $\theta^{\circ}$. To better understand the individual affects of varying production and consumption shares, we varied $\chi^{o}$ while holding $\theta^{o}$ fixed at the baseline calibration of 0.135 and using the baseline calibration for the elasticities of oil supply and demand. We find that there is a critical value of $\chi^{o}$ around 0.52 where the welfare effect of removing the subsidies on country $o$ switches from positive to negative; values of $\chi^{o}$ above 0.52 imply negative welfare effects of removing the subsidy while values below 0.52 lead to welfare gains. As $\chi^{o}$ increases, the import elasticity of demand in country $a$ declines and the costs to country o of removing the subsidy increase. Eventually this channel dominates the outcome and 
welfare declines when the subsidy is removed. Similarly, we varied $\theta^{o}$ while holding $\chi^{o}$ fixed at the benchmark value of 0.48 . Here also we find a critical value of $\theta^{\circ}$ of around 0.05 where the welfare effects of removing the subsidies switches from positive to negative; values of $\theta^{\circ}$ below 0.05 result in a decline in welfare for country $o$ while values above 0.05 lead to welfare gains.

\section{Concluding Remarks}

In this paper, we used a two country, two good, general equilibrium model to examine the impact that oil price subsidies have on the oil market and the trade of non-oil goods. We calibrated the model to match the most recent data. In our baseline case, we found that the removal of subsidies resulted in a six percent decline in oil prices and was welfare enhancing for both the importing and exporting countries.

We also showed how the effects of removing existing subsidies depend on oil supply and demand elasticities, as well as the share of world oil production and consumption due to the subsidizers. The welfare effects on oil importing countries were unambiguously positive for all the cases considered. However, in certain cases removing the subsidies was actually found to be welfare reducing for the subsidizing countries. This occurs if oil supply or demand is relatively inelastic, and when the subsidizers produce a large enough share of the world's oil supply relative to what they consume.

Several avenues for future research suggest themselves. First, while our model was explicitly dynamic, our examination of the effect of removing oil price subsidies was entirely steady state. The transition from initial steady state, where there are substantial subsidies, to a new steady state in which the subsidies are removed may give rise to intertemporal trade-offs that might alter the welfare comparisons. Along similar lines, a richer and dynamic model of oil supply might suggest additional intertemporal tradeoffs. A closer examination of how these subsidies are financed (here we assumed they were financed by lump-sum transfers/taxes) might also alter welfare implications of the subsidies.

A final issue of interest may be the reduction of carbon emissions associated with the removal of subsidies. By changing the level of global oil consumption, oil product subsidies also affect global carbon emissions and local pollution levels. A very rough calculation using our baseline scenario puts the decline in global $\mathrm{CO}_{2}$ emissions from the removal of the subsidies at $0.75 \%$ of total $\mathrm{CO}_{2}$ emissions in $2012 .{ }^{6}$ Another avenue of research would

\footnotetext{
${ }^{6}$ The appendix provides the details of this calculation.
} 
be to undertake a more rigorous analysis of this issue. 


\section{References}

[1] Baumeister, Christiane and Gert Peersman (2013). "The role of timevarying price elasticities in accounting for volatility changes in the crude oil market." Journal of Applied Econometrics 28 (7): 1087 - 1109.

[2] Coady, David, Moatz El-Said, Robert Gillingham, Kangni Kpodar, Paulo Medas, and David Newhouse (2006). "The magnitude and distribution of fuel subsidies: evidence from Bolivia, Ghana, Jordan, Mali, and Sri Lanka." IMF Working Paper WP/06/247.

[3] Deutsche Gesellschaft fur Internationale Zusammenarbeit (2011). International Fuel Prices Survey 2010/2011.

[4] Graham, Daniel J. and Stephen Glaister (2002). "The Demand for Automobile Fuel: A Survey of Elasticities." Journal of Transport Economics and Policy 36 (1): $1-26$

[5] Hartley, Peter and Kenneth B. Medlock III (2008). "A model of the operation and development of a national oil company." Energy Economics 30 (5): $2459-2485$

[6] Hausman, J. and W. Newey (1995). "Nonparametric Estimation of Exact Consumer Surplus and Deadweight Loss." Econometrica 63 (6): $1445-1476$

[7] IEA (2010). World Energy Outlook 2010.

[8] Kilian, Lutz and Daniel P. Murphy (2014). "The role of inventories and speculative trading in the global market for crude oil." Journal of Applied Econometrics 29 (3): $454-478$

[9] Kpodar, Kangni (2006). "Distributional Effects of Oil Price Changes on Household Expenditures: Evidence from Mali." IMF Working Paper, $\mathrm{WP} / 06 / 91$.

[10] Plante, Michael (2014). "The long-run macroeconomic impact of fuel subsidies." Journal of Development Economics 107: 129-143.

[11] Yatchew, Adonis and Joungyeo Angela No (2001). "Household Gasoline Demand in Canada." Econometrica 69 (6): 1697 - 1709 
Table 1: Countries identified as subsidizers

$\begin{array}{ll}\text { Algeria } & \text { Libya } \\ \text { Angola } & \text { Malaysia } \\ \text { Azerbaijan } & \text { Nigeria } \\ \text { Bahrain } & \text { Oman } \\ \text { Bolivia } & \text { Qatar } \\ \text { Brunei } & \text { Saudi Arabia } \\ \text { Ecuador } & \text { Sudan } \\ \text { Egypt } & \text { Syria } \\ \text { Indonesia } & \text { Turkmenistan } \\ \text { Iran } & \text { United Arab Emirates } \\ \text { Iraq } & \text { Venezuela } \\ \text { Kuwait } & \text { Yemen }\end{array}$


Table 2: Statistics about the 24 countries

$\begin{array}{ccc}\text { Year } & \begin{array}{c}\text { Share of world } \\ \text { oil consumption }\end{array} & \begin{array}{c}\text { Share of world } \\ \text { oil production }\end{array} \\ 1992 & 9.5 & 46.1 \\ 1993 & 9.9 & 47.3 \\ 1994 & 10.0 & 47.6 \\ 1995 & 10.0 & 47.7 \\ 1996 & 10.0 & 47.5 \\ 1997 & 10.2 & 48.0 \\ 1998 & 10.2 & 48.8 \\ 1999 & 10.2 & 48.1 \\ 2000 & 10.4 & 48.9 \\ 2001 & 10.8 & 47.9 \\ 2002 & 11.0 & 46.2 \\ 2003 & 11.1 & 46.6 \\ 2004 & 11.3 & 47.8 \\ 2005 & 11.6 & 48.9 \\ 2006 & 11.8 & 48.6 \\ 2007 & 12.1 & 48.4 \\ 2008 & 12.9 & 49.4 \\ 2009 & 13.0 & 48.1 \\ 2010 & 13.1 & 48.3 \\ 2011 & 13.4 & 48.1 \\ 2012 & 13.5 & 47.9\end{array}$


Table 3: Steady state moments and parameter values

\begin{tabular}{ll}
\hline Investment in $a\left(A_{I}^{a}\right)$ & 20 percent of $a$ 's GDP \\
Consumption-expenditure share of fuel in $a$ & 5 percent \\
Firm use of oil in $a\left(P_{o} O_{y}^{a}\right)$ & 2 percent of $a$ 's GDP \\
Consumption of fuel in $o$ & 13.5 percent of world consumption \\
Oil production in $o$ & 48 percent of world production \\
Ratio of subsidized price to world price $\left(\frac{P_{s}}{P_{o}}\right)$ & .34 \\
Elasticity of supply $\left(\eta^{a}, \eta^{o}\right)$ & .30 \\
Discount factor $(\beta)$ & .96 \\
Elasticities of substitution $\left(\frac{1}{\mu_{c}}, \frac{1}{\nu}\right)$ & .75 \\
Risk aversion parameter $(\sigma)$ & 2 \\
Frisch elasticity of labor supply $\left(\frac{1}{\mu_{n}}\right)$ & 1 \\
Labor share in production of $a(\alpha)$ & .70
\end{tabular}


Table 4: Effects of removing the oil subsidies in baseline model

\begin{tabular}{lc}
\hline Variables & Baseline \\
\hline Prices & \\
market oil price $\left(P_{o}\right)$ & -6.1 \\
subsidized oil price $\left(P_{s}\right)$ & 176.0 \\
& \\
Country o variables & \\
$\quad$ oil production $\left(Y_{o}^{o}\right)$ & -1.9 \\
oil consumption $\left(O_{c}^{o}\right)$ & -45.9 \\
consumption of good A $\left(A_{c}^{o}\right)$ & 15.9 \\
transfers $(\mathrm{T})$ & 21.4 \\
welfare & 0.86
\end{tabular}

\section{Country a variables}

oil production $\left(Y_{o}^{a}\right) \quad-1.9$

oil used in consumption $\left(O_{c}^{a}\right) \quad 4.9$

oil used in production $\left(O_{y}^{a}\right) \quad 5.2$

consumption of good A $\left(A_{c}^{a}\right) \quad 0.004$

non-oil GDP 0.23

welfare 0.23

\section{World variables}

World oil consumption $\quad-1.9$

Note: Variables are in percent change across steady states. The new steady state is the one without subsidies. Welfare is in consumption-equivalent percentages. 
Table 5: Effects of removing oil subsidies for different elasticities of supply

\begin{tabular}{|c|c|}
\hline Variables & $\eta^{j}=0.3$ \\
\hline
\end{tabular}

(Baseline)

\section{Prices}

market oil price $\left(P_{o}\right)$

subsidized oil price $\left(P_{s}\right)$

$\begin{array}{cccc}-5.5 & -6.1 & -6.9 & -7.9 \\ 178.0 & 176.0 & 173.8 & 171.0\end{array}$

\section{Country o variables}

oil production $\left(Y_{o}^{o}\right)$

oil consumption $\left(O_{c}^{o}\right)$

consumption of good $\mathrm{A}\left(A_{c}^{o}\right)$

transfers $(\mathrm{T})$

welfare

\section{Country a variables}

$\begin{array}{cccc}-2.2 & -1.9 & -1.4 & -0.8 \\ -44.9 & -45.9 & -46.8 & -47.6 \\ 18.6 & 15.9 & 13.3 & 10.7 \\ 24.8 & 21.4 & 18.0 & 14.8 \\ 1.64 & 0.86 & 0.03 & -0.87\end{array}$

oil production $\left(Y_{o}^{a}\right)$

oil used in consumption $\left(O_{c}^{a}\right)$

oil used in production $\left(O_{y}^{a}\right)$

consumption of good $\mathrm{A}\left(A_{c}^{a}\right)$

non-oil GDP

welfare

$-2.2$

4.3

4.6

0.004

0.20

0.20

World oil consumption
$-2.2$

\section{World variables}

$-1.4 \quad-0.8$

$\begin{array}{lll}4.9 & 5.5 & 6.3\end{array}$

$\begin{array}{lll}5.2 & 5.9 & 6.8\end{array}$

$\begin{array}{lll}0.004 & 0.005 & 0.006\end{array}$

$\begin{array}{lll}0.23 & 0.26 & 0.29\end{array}$

$\begin{array}{lll}0.23 & 0.26 & 0.29\end{array}$

$\begin{array}{lll}-1.9 & -1.4 & -0.8\end{array}$

Note: Variables are in percent change across steady states. The new steady state is the one without subsidies. Welfare is in consumption-equivalent percentages. 
Table 6: Effects of removing the oil subsidies for different demand elasticities

\begin{tabular}{lcccc}
\hline Variables & $\begin{array}{c}.75 \\
\text { (Baseline) }\end{array}$ & .65 & .55 & .45 \\
\hline
\end{tabular}

$\begin{array}{lcccc}\text { Prices } & & & & \\ \text { market oil price }\left(P_{o}\right) & -6.1 & -6.1 & -5.9 & -5.7 \\ \text { subsidized oil price }\left(P_{s}\right) & 176.0 & 176.3 & 176.7 & 177.4 \\ \text { Country o variables } & & & & \\ \quad \text { oil production }\left(Y_{o}^{o}\right) & -1.9 & -1.9 & -1.8 & -1.7 \\ \quad \text { oil consumption }\left(O_{c}^{o}\right) & -45.9 & -41.3 & -36.5 & -31.3 \\ \quad \text { consumption of good A }\left(A_{c}^{o}\right) & 15.9 & 13.5 & 11.2 & 8.7 \\ \quad \text { transfers (T) } & 21.4 & 21.5 & 21.7 & 22.1 \\ \quad \text { welfare } & 0.86 & 0.14 & -0.54 & -1.15 \\ \text { Country a variables } & & & & \\ \quad \text { oil production }\left(Y_{o}^{a}\right) & -1.9 & -1.9 & -1.8 & -1.7 \\ \quad \text { oil used in consumption }\left(O_{c}^{a}\right) & 4.9 & 4.2 & 3.5 & 2.8 \\ \quad \text { oil used in production }\left(O_{y}^{a}\right) & 5.2 & 4.5 & 3.8 & 3.1 \\ \quad \text { consumption of good A }\left(A_{c}^{a}\right) & 0.004 & 0.036 & 0.067 & 0.094 \\ \quad \text { non-oil GDP } & 0.23 & 0.23 & 0.24 & 0.24 \\ \quad \text { welfare } & 0.23 & 0.23 & 0.22 & 0.22 \\ \quad & & & & \\ \text { World variables } & & & & \\ \quad \text { World oil consumption } & -1.9 & -1.9 & -1.8 & -1.7\end{array}$

Note: Variables are in percent change across steady states. The new steady state is the one without subsidies. Welfare is in consumption-equivalent percentages. 
Table 7: Effects of removing oil subsidies for alternative shares of oil consumption and production

\begin{tabular}{lccc}
\hline Variables & Saudi & Top 5 consumers & Baseline \\
\hline & & & \\
Share of world consumption $\left(\theta^{o}\right)$ & $3 \%$ & $8.2 \%$ & $13.5 \%$ \\
Share of world production $\left(\chi^{o}\right)$ & $13 \%$ & $23 \%$ & $48 \%$ \\
Prices & & & \\
market oil price $\left(P_{o}\right)$ & -1.3 & -3.3 & -6.2 \\
subsidized oil price $\left(P_{s}\right)$ & 190.2 & 184.5 & 176 \\
& & & \\
Country o variables & & & \\
oil production $\left(Y_{o}^{o}\right)$ & -0.4 & -1.0 & -1.9 \\
oil consumption $\left(O_{c}^{o}\right)$ & -47.0 & -41.0 & -45.9 \\
consumption of good A $\left(A_{c}^{o}\right)$ & 18.0 & 29.2 & 15.9 \\
transfers (T) & 22.5 & 38.0 & 21.4 \\
welfare & 4.96 & 5.77 & 0.86 \\
& & & \\
Country a variables & & & -1.9 \\
oil production $\left(Y_{o}^{a}\right)$ & -0.4 & -1.0 & 4.9 \\
oil used in consumption $\left(O_{c}^{a}\right)$ & 1.0 & 2.5 & 5.2 \\
oil used in production $\left(O_{y}^{a}\right)$ & 1.1 & 2.7 & 0.00 \\
consumption of good A $\left(A_{c}^{a}\right)$ & -0.01 & -0.02 & 0.23 \\
non-oil GDP & 0.07 & 0.16 & 0.23 \\
welfare & 0.02 & 0.06 &
\end{tabular}

Note: Variables are in percent change across steady states. The new steady state is the one without subsidies. Welfare is in consumption-equivalent percentages. 
Figure 1: Ratio of subsidized prices to U.S. prices

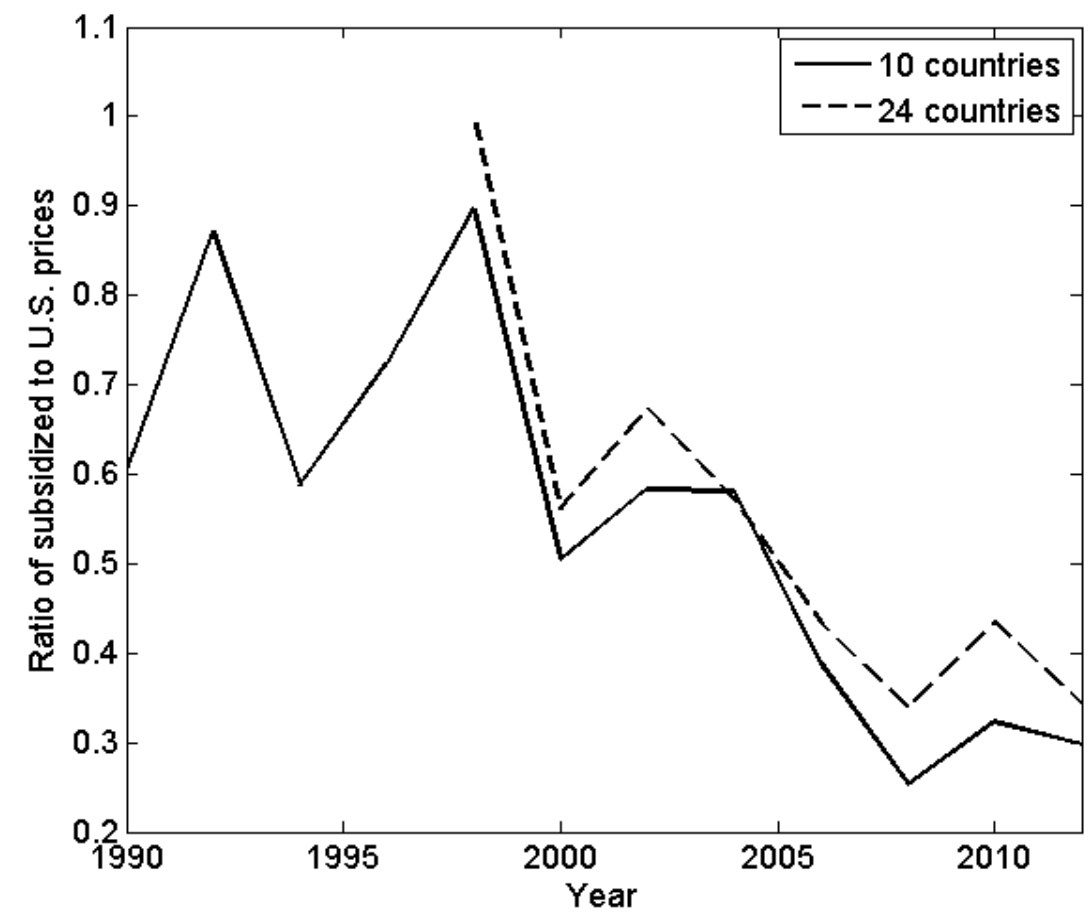




\section{A Appendix (Not for publication)}

\section{A.1 Data sources}

- Algeria - OPEC Annual Statistical Bulletins

- Angola - World Bank data

- Azerbaijan - World Bank data

- Bahrain - World Bank data

- Bolivia - World Bank data

- Brunei - World Bank data

- Ecuador - World Bank data

- Egypt - World Bank data

- Indonesia - OPEC Annual Statistical Bulletins (1990 - 2008), media reports on government announced fuel price changes (2008 - 2012)

- Iran - OPEC Annual Statistical Bulletins

- Iraq - GIZ International Fuel Prices survey, IMF, OPEC Annual Statistical Bulletins

- Kuwait - OPEC Annual Statistical Bulletins

- Libya - OPEC Annual Statistical Bulletins

- Malaysia - World Bank data

- Nigeria - OPEC Annual Statistical Bulletins

- Oman - World Bank data

- Qatar - OPEC Annual Statistical Bulletins

- Saudi Arabia - OPEC Annual Statistical Bulletins

- Sudan - World Bank data

- Syria - World Bank data

- Turkmenistan - World Bank data 
- United Arab Emirates - OPEC Annual Statistical Bulletins

- Venezuela - OPEC Annual Statistical Bulletins

- Yemen - World Bank data 


\section{A.2 Calculating the welfare changes across steady states}

Suppose $X_{1}$ and $X_{2}$ are the steady state values of variable $X$ in the original and the new steady state, respectively. Then the change in aggregate welfare across steady states for country $a$ is given by

$$
\frac{1}{1-\beta}\left\{\left[\frac{\left(C_{2}^{a}\right)^{1-\sigma}}{1-\sigma}-\kappa \frac{\left(N_{2}^{a}\right)^{1+\mu_{n}}}{1+\mu_{n}}\right]-\left[\frac{\left(C_{1}^{a}\right)^{1-\sigma}}{1-\sigma}-\kappa \frac{\left(N_{1}^{a}\right)^{1+\mu_{n}}}{1+\mu_{n}}\right]\right\} .
$$

The change in welfare in country $o$ can be calculated similarly.

Looking at the change in aggregate welfare across steady states is not very informative because of the units. To make the comparisons more concrete, we solve for how much aggregate consumption in the new steady state would need to be increased or decreased, in percentage points, to make welfare equal across the two steady states. Mathematically we solve for $\omega$ in the following equation,

$$
\left\{\left[\frac{\left(\omega C_{2}^{a}\right)^{1-\sigma}}{1-\sigma}-\kappa \frac{\left(N_{2}^{a}\right)^{1+\mu_{n}}}{1+\mu_{n}}\right]-\left[\frac{\left(C_{1}^{a}\right)^{1-\sigma}}{1-\sigma}-\kappa \frac{\left(N_{1}^{a}\right)^{1+\mu_{n}}}{1+\mu_{n}}\right]\right\}=0 .
$$

In general $\omega$ will be non-zero as welfare will be higher or lower across steady states. The welfare losses are calculated as

$$
W_{l}=100 *(1-\omega)
$$

$W_{l}$ will be negative when $\omega>1$, which occurs when aggregate welfare is lower in the new steady state. Aggregate consumption would need to be increased by $W_{l}$ percent to get utility in the new steady state back up to its initial level in the old steady state.

On the flip side, $W_{l}$ will be positive when $\omega<1$, which occurs when aggregate welfare is higher in the new steady state. In that case, aggregate consumption would need to be lowered by $W_{l}$ percent to get utility in the new steady state back down its lower level in the old steady state. 


\section{A.3 Carbon calculations}

Our estimate of a $0.75 \%$ reduction in carbon emissions is a very rough calculation based on the following numbers.

Crude oil energy content (Source: EIA)

$1 \mathrm{bbl}$ of crude $=5.8 \mathrm{MMBtu}$

Crude oil emissions (Source: EIA)

$164.3 \mathrm{lbs}$ of $\mathrm{CO}_{2}$ per MMBtu

Global carbon emissions (Source: http://co2now.org/current-co2/co2-

Now/global-carbon-emissions.html)

$35.6 * 10^{9}$ metric tons of $\mathrm{CO}_{2}$ in 2012

\section{Calculations}

2012 world consumption: $89.17 \mathrm{mb} / \mathrm{d}$ (Source: EIA)

$1.9 \%$ decline in consumption $=1.69 \mathrm{mb} / \mathrm{d}$ decline $=616,850,000 \mathrm{bbl}$

$616.85 * 10^{6}$ barrels $* 5,800,000 \mathrm{Btu} /$ barrel $=3577.7 * 10^{6} \mathrm{MMBtu}$

$3577.7 * 10^{6} \mathrm{MMBtu} * 164.3 \mathrm{lbs} \mathrm{CO}_{2} / \mathrm{MMBtu}=587.82 * 10^{9} \mathrm{lbs} \mathrm{CO}_{2}$

1 metric ton $=2204 \mathrm{lbs}$

$266.71 * 10^{6}$ metric tons

Percent reduction

$\left(100^{*}\left(266.71^{*} 10^{6}\right) /\left(35.6^{*} 10^{9}\right)\right)=.75 \%$ 


\section{A.4 Model equations}

First order conditions for household in $a$

$$
\begin{gathered}
{\left[\left(1-\gamma_{o}^{a}\right)\left(A_{c, t}^{a}\right)^{1-\mu_{c}}+\left(\gamma_{o}^{a}\right)\left(O_{c, t}^{a}\right)^{1-\mu_{c}}\right]^{\frac{1-\sigma}{1-\mu_{c}}-1}\left(1-\gamma_{o}^{a}\right)\left(A_{c, t}^{a}\right)^{-\mu_{c}}=\lambda_{t}^{a},} \\
{\left[\left(1-\gamma_{o}^{a}\right)\left(A_{c, t}^{a}\right)^{1-\mu_{c}}+\left(\gamma_{o}^{a}\right)\left(O_{c, t}^{a}\right)^{1-\mu_{c}}\right]^{\frac{1-\sigma}{1-\mu_{c}}-1} \gamma_{o}^{a}\left(O_{c, t}^{a}\right)^{-\mu_{c}}=P_{o, t} \lambda_{t}^{a}} \\
\kappa\left(N_{t}^{a}\right)^{\mu_{c}}=W_{t}^{a} \lambda_{t}^{a}, \\
\lambda_{t}^{a}=\beta E_{t} \lambda_{t+1}^{a}\left[r_{t+1}^{a}+(1-\delta) .\right]
\end{gathered}
$$

Law of motion for capital

$$
K_{t}^{a}-K_{t-1}^{a}=A_{I, t}^{a}-\delta K_{t-1}^{a} .
$$

Production function for good $a$

$$
Y_{a, t}^{a}=Z_{y, t}^{a} N_{t}^{a \alpha}\left[\omega_{y}^{a} K_{t-1}^{a 1-\nu}+\left(1-\omega_{y}^{a}\right) O_{y, t}^{a 1-\nu}\right]^{\frac{1-\alpha}{1-\nu}} .
$$

First order conditions for the firm

$$
\begin{aligned}
& \alpha \frac{Y_{a, t}^{a}}{N_{t}^{a}}=W_{t}^{a} \\
& (1-\alpha) Y_{a, t}^{a} \frac{\omega_{y}^{a}\left(K_{t-1}^{a}\right)^{-\nu}}{\omega_{y}^{a} K_{t-1}^{a 1-\nu}+\left(1-\omega_{y}^{a}\right) O_{y, t}^{a 1-\nu}}=r_{t}^{a} \\
& (1-\alpha) Y_{a, t}^{a} \frac{\left(1-\omega_{y}^{a}\right) O_{y, t}^{a-\nu}}{\omega_{y}^{a} K_{t-1}^{a 1-\nu}+\left(1-\omega_{y}^{a}\right) O_{y, t}^{a 1-\nu}}=P_{o, t}
\end{aligned}
$$

Costs in the oil sector in country $a$

$$
A_{y, t}^{a}=\varkappa_{a} \frac{\left(Y_{o, t}^{a}\right)^{1+\frac{1}{\eta^{a}}}}{1+\frac{1}{\eta^{a}}} .
$$

First order condition for the oil sector in $a$

$$
P_{o, t}=\varkappa_{a}\left(Y_{o, t}^{a}\right)^{\frac{1}{\eta^{a}}} .
$$

Market clearing condition for good $A$

$$
A_{c, t}^{a}+A_{I, t}^{a}+A_{y, t}^{a}+A_{c, t}^{o}+A_{y, t}^{o}=Y_{a, t}^{a} .
$$


Market clearing condition for the oil market

$$
O_{c, t}^{a}+O_{y, t}^{a}+O_{c, t}^{o}=Y_{o, t}^{o}+Y_{o, t}^{a} .
$$

Current account equation for country $a$

$$
P_{o, t}\left(O_{c, t}^{a}+O_{y, t}^{a}-Y_{o, t}^{a}\right)=Y_{a, t}^{a}-A_{c, t}^{a}-A_{I, t}^{a}-A_{y, t}^{a} .
$$

First order conditions for household in $o$

$$
\begin{gathered}
{\left[\left(1-\gamma_{o}^{o}\right)\left(A_{c, t}^{o}\right)^{1-\mu_{c}}+\left(\gamma_{o}^{o}\right)\left(O_{c, t}^{o}\right)^{1-\mu_{c}}\right]^{\frac{1-\sigma}{1-\mu_{c}}-1}\left(1-\gamma_{o}^{o}\right)\left(A_{c, t}^{o}\right)^{-\mu_{c}}=\lambda_{o, t},} \\
{\left[\left(1-\gamma_{o}^{o}\right)\left(A_{c, t}^{o}\right)^{1-\mu_{c}}+\left(\gamma_{o}^{o}\right)\left(O_{c, t}^{o}\right)^{1-\mu_{c}}\right]^{\frac{1-\sigma}{1-\mu_{c}}-1} \gamma_{o}^{o}\left(O_{c, t}^{o}\right)^{-\mu_{c}}=P_{t}^{s} \lambda_{o, t}}
\end{gathered}
$$

Costs in the oil sector in country $o$

$$
A_{y, t}^{o}=\varkappa_{o} \frac{\left(Y_{o, t}^{o}\right)^{1+\frac{1}{\eta^{o}}}}{1+\frac{1}{\eta^{o}}} .
$$

First order condition for the oil sector in $o$

$$
P_{o, t}=\varkappa_{o}\left(Y_{o, t}^{o}\right)^{\frac{1}{\eta^{o}}} .
$$

Government budget constraint in country $o$

$$
P_{o, t}\left(Y_{o}^{o}-O_{c, t}^{o}\right)+P_{s, t} O_{c, t}^{o}-A_{y, t}^{o}=T_{t}
$$

\section{A.5 Steady state equations}

$$
\begin{gathered}
{\left[\left(1-\gamma_{o}^{a}\right)\left(A_{c}^{a}\right)^{1-\mu_{c}}+\left(\gamma_{o}^{a}\right)\left(O_{c}^{a}\right)^{1-\mu_{c}}\right]^{\frac{1-\sigma}{1-\mu_{c}}-1}\left(1-\gamma_{o}^{a}\right)\left(A_{c}^{a}\right)^{-\mu_{c}}=\lambda_{a}} \\
{\left[\left(1-\gamma_{o}^{a}\right)\left(A_{c}^{a}\right)^{1-\mu_{c}}+\left(\gamma_{o}^{a}\right)\left(O_{c}^{a}\right)^{1-\mu_{c}}\right]^{\frac{1-\sigma}{1-\mu_{c}}-1} \gamma_{o}^{a}\left(O_{c}^{a}\right)^{-\mu_{c}}=P^{o} \lambda_{a}} \\
\kappa N^{a} \mu_{c}=W^{a} \lambda^{a} \\
\frac{1}{\beta}-1+\delta=r^{a} . \\
\delta K^{a}=A_{I}^{a} . \\
Y_{a}^{a}=Z_{y}^{a} N^{a \alpha}\left[\omega_{y}^{a} K^{a 1-\nu}+\left(1-\omega_{y}^{a}\right) O_{y}^{a}{ }^{1-\nu}\right]^{\frac{1-\alpha}{1-\nu}} \\
\alpha \frac{Y_{a}^{a}}{N^{a}}=W^{a}
\end{gathered}
$$




$$
\begin{gathered}
(1-\alpha) Y_{a}^{a} \frac{\omega_{y}^{a}\left(K^{a}\right)^{-\nu}}{\omega_{y}^{a}\left(K^{a}\right)^{1-\nu}+\left(1-\omega_{y}^{a}\right)\left(O_{y}^{a}\right)^{1-\nu}}=r^{a} \\
(1-\alpha) Y_{a}^{a} \frac{\left(1-\omega_{y}^{a}\right) O_{y}^{a}-\nu}{\omega_{y}^{a} K^{a} 1-\nu+\left(1-\omega_{y}^{a}\right) O_{y}^{a} 1-\nu}=P_{o} \\
A_{y}^{a}=\varkappa_{a} \frac{\left(Y_{o}^{a}\right)^{1+\frac{1}{\eta^{a}}}}{1+\frac{1}{\eta^{a}}} . \\
P_{o}=\varkappa_{a}\left(Y_{o}^{a}\right)^{\frac{1}{\eta^{a}}} . \\
A_{c}^{a}+A_{I}^{a}+A_{y}^{a}+A_{c}^{o}+A_{y}^{o}=Y_{a}^{a} \\
O_{c}^{a}+O_{y}^{a}+O_{c}^{o}=Y_{o}^{o}+Y_{o}^{a} \\
P_{o}\left(O_{c}^{a}-Y_{o}^{a}\right)=Y_{a}^{a}-A_{c}^{a}-A_{I}^{a}-A_{y}^{a} . \\
{\left[\left(1-\gamma_{o}^{o}\right)\left(A_{c}^{o}\right)^{1-\mu_{c}}+\left(\gamma_{o}^{o}\right)\left(O_{c}^{o}\right)^{1-\mu_{c}}\right]^{\frac{1-\sigma}{1-\mu_{c}}-1}\left(1-\gamma_{o}^{o}\right)\left(A_{c}^{o}\right)^{-\mu_{c}}=\lambda^{o},} \\
{\left[\left(1-\gamma_{o}^{o}\right)\left(A_{c}^{o}\right)^{1-\mu_{c}}+\left(\gamma_{o}^{o}\right)\left(O_{c}^{o}\right)^{1-\mu_{c}}\right]^{\frac{1-\sigma}{1-\mu_{c}}-1} \gamma_{o}^{o}\left(O_{c}^{o}\right)^{-\mu_{c}}=P_{s} \lambda^{o},} \\
P_{o}\left(Y_{o}^{o}-O_{c}^{o}\right)+P_{s} O_{c}^{o}-A_{y}^{o}=T .
\end{gathered}
$$

